Int. J. Plant Sci. 172(4):530-540. 2011.

(c) 2011 by The University of Chicago. All rights reserved.

1058-5893/2011/17204-0006\$15.00 DOI: $10.1086 / 658924$

\title{
TRACKING THE ORIGIN OF INVASIVE ROSA RUBIGINOSA POPULATIONS IN ARGENTINA
}

\author{
Heidi Hirsch, ${ }^{1, *}$ Heike Zimmermann, ${ }^{*}$ Christiane M. Ritz, † Volker Wissemann, $\neq$ Henrik von Wehrden, ${ }^{*} \S$ \\ Daniel Renison, $\|$ Karsten Wesche, † Erik Welk,* and Isabell Hensen*
}

\begin{abstract}
*Institute of Biology, Geobotany and Botanical Garden, Martin-Luther-University Halle-Wittenberg, Am Kirchtor 1, 06108 Halle/Saale, Germany; †Senckenberg Museum of Natural History Goerlitz, Am Museum 1, 02826 Goerlitz, Germany; łInstitute of Botany and Plant Physiology, Systematic Botany, Justus-Liebig-University Giessen, Heinrich-Buff-Ring 38, 35392 Giessen, Germany; §Institute of Ecology and Environmental Chemistry Fac. III, Centre of Methods, Leuphana University, Scharnhorststraße 1, 21335 Lueneburg, Germany; and $\|$ Institute of Ecology, Facultad de Ciencias Exactas, Físicas y Naturales, National University Córdoba, Consejo Nacional de Investigaciones Científicas y Técnicas, Avénida Vélez Sarsfield 229, 5000 Córdoba, Argentina
\end{abstract}

The exact geographic origin of invasive species populations is rarely known; however, such knowledge is vital to understanding species' invasion success, spread, and evolution as well as for assessing any biological control options. We investigated the shrub Rosa rubiginosa L., focusing on the presumed European origin of invasive populations in Argentina. We analyzed eight polymorphic microsatellite loci among 102 native (European) and 29 invasive (mainly central Argentinean and Patagonian) populations. Genetic diversity in the invasive range was clearly lower than in the native range, possibly because of a low number of introductions. Contrary to earlier hypotheses, the interpretation of principal coordinate analysis results and Jaccard dissimilarities contradicts the idea of the Argentinean populations having a Spanish origin. Instead, we found a close similarity between Argentinean samples and those from Germany, the Czech Republic, and Austria. We therefore assume that these neighboring countries are the most probable source regions for the Argentinean populations, which in some cases may also have arrived via Chile. According to historic information, emigrants from these regions may have introduced R. rubiginosa to South America in the nineteenth century on at least two occasions, either for food or as rootstock material for propagating living fences.

Keywords: biological invasions, microsatellites, native origin, bridgehead effect, polyploidy, Rosaceae.

Online enhancement: appendix B.

\section{Introduction}

The discovery of America by Christopher Columbus in 1492 was a crucial event in human history and nature. Since the discovery of the New World, globalization of trade, transport, and emigration has been constantly growing, and humans have played an increasing role in the dispersal of species (Meyerson and Mooney 2007). As a consequence, many species have become introduced to areas where they could not have naturally dispersed. Some of these species became so successful after establishment that they are regarded as being invasive in their new ranges (Richardson et al. 2000).

It is predicted that most invasive populations develop from a few introduced individuals, and these initially small populations are generally expected to have a low genetic diversity because of founder effects and genetic drift (Dlugosch and Parker 2008a; Novak and Mack 2005). However, the magnitude of these effects depends on several factors, for example, the reproduction system (Novak and Mack 2005; Barrett et al. 2008), the ploidy level (Soltis and Soltis 2000; Prentis

\footnotetext{
${ }^{1}$ Author for correspondence; e-mail: hirsch-heidi@web.de.
}

Manuscript received September 2010; revised manuscript received December 2010. et al. 2008), or preadaptations to abiotic influences (Prinzing et al. 2002; Schlaepfer et al. 2010). Therefore, invasive species can be very successful despite having low genetic variability (Ahmad et al. 2008; Le Roux et al. 2008). Detailed insights into these aspects of invasion success can often be gained by comparing invasive and native populations of the invasive species (Bossdorf et al. 2005; Erfmeier and Bruelheide 2005; Hierro et al. 2005).

Identification of the exact geographic origin of source populations of invasive species provides important information about success, spread, and evolution of invasive species and creates opportunities for their biological control (e.g., hostspecific pathogens; Guo 2006; Estoup and Guillemaud 2010). Molecular markers are appropriate tools for identifying the source populations of invasive species, since they enable the detection of pathways of introduction and allow for comparisons between the species' genetic variation in the native and invasive ranges (Barrett and Shore 1989; Sakai et al. 2001; Durka et al. 2005). Nonetheless, only a few studies have determined the source populations of invasive species (Milne and Abbott 2004; Gaskin et al. 2005; Goolsby et al. 2006). One example is the study by Novak and Mack (2001), who used allozyme electrophoresis techniques in combination with historical information to trace the native source region of invasive Bromus tectorum L. populations in North America as 
well as other naturalized ranges (Argentina, Chile, Canary Islands, Hawaii, and New Zealand). They revealed that its spread was closely related to patterns of European human immigration around the world. Similarly, Besnard et al. (2007) determined the origin of invasive olive trees (Olea europaea L.) in Australia and Hawaii on the basis of microsatellites and chloroplast markers as well as ITS sequences.

Rosa rubiginosa $\mathrm{L}$. (Rosaceae), the sweet briar or eglantine rose, is native to Eurasia (Täckholm 1922; Meusel et al. 1965 ) and forms neophytic or even invasive populations in South Africa, Australia, New Zealand, and North and South America (Parsons and Cuthbertson 2001; Weber 2003; Bellingham et al. 2004; Nel et al. 2004; Lüttig 2006). In Argentina, populations of $R$. rubiginosa are mainly located in central Argentina and Patagonia. In Patagonia, the rose is widespread and populations most often take the form of dense stands that displace native species (Damascos and Gallopin 1992). Here, R. rubiginosa is already accepted as part of the local flora, and rose hips are harvested for private use or by small producers. In Chile, on the other hand, R. rubiginosa is already being exploited on a large scale for its seed oil by international cosmetic companies (Joublan and Rios 2005). In central Argentina, populations are smaller than in Patagonia but equally invasive (Zimmermann et al. 2010). The exact Eurasian origin of the Argentinean populations is unknown. In accordance with the predominant European origin of human immigrants, two scenarios are currently discussed in the literature: (1) R. rubiginosa was introduced to South America by Spanish immigrants (Joublan et al. 1996; Leuenberger 2005; Lüttig 2006) or (2) German immigrants brought $R$. rubiginosa to South America (Damascos 1992).

A comparison of 13 Argentinean and 20 native populations (Germany and Spain) using dominant random amplification of polymorphic DNA and codominant microsatellite markers by Zimmermann et al. (2010) revealed that genetic diversity of $R$. rubiginosa is highly reduced in the invasive range, but they were unable to detect the geographic origin of the invasive populations. However, one Argentine population was genetically very similar to German populations. In this study, we extended our sampling with the focus on Germany and its neighboring countries and Spain in the native range and therefore analyzed $R$. rubiginosa populations in a wider distribution range than in our previous study by using both fresh and herbarium plants. Herbarium material provides the additional advantage that genetic information from extinct populations can be used. Furthermore, we used nuclear microsatellite markers because of their expected higher genetic variability and good reproducibility (Litt and Luty 1989; Tautz 1989). We assessed the following questions: (1) Is it possible to track the European origin of the $R$. rubiginosa invasion in Argentina and to estimate how many introduction events occurred? (2) Can we confirm the low genetic diversity of $R$. rubiginosa in the invasive range?

\section{Material and Methods}

\section{Study Species}

Rosa rubiginosa is one of $\sim 60$ species of the section Caninae (DC.) Ser. (dog roses; Wissemann and Ritz 2007). Dog roses reproduce by xenogamy and autogamy, but apomixis has also been described (Wissemann and Hellwig 1997). The species of this section are characterized by an unusual meiotic system, the canina meiosis, first described by Täckholm (1920, 1922) and Blackburn and Harrison (1921). Their studies revealed that most dog roses, including R. rubiginosa, are pentaploid $(2 n=5 x=35)$. The unique canina meiosis produces tetraploid egg cells $(1 \mathrm{n}=4 \mathrm{x}=28)$-which stabilizes this odd ploidy level, thus ensuring sexual reproduction-and haploid sperm cells $(1 \mathrm{n}=1 \mathrm{x}=7)$. This leads to distinctive matroclinal inheritance (Ritz and Wissemann 2003; Wissemann et al. 2006; Wissemann and Ritz 2007) and renders analysis of heterozygosity and related genetic measures complicated.

\section{Sampling Scheme}

On the basis of the two currently discussed scenarios regarding the origin of invasive $R$. rubiginosa populations in South America, we focused our sampling in the native range on Spain (42 samples) and Germany (201 samples). According to recommendations by Muirhead et al. (2008), we also increased the population sampling with other countries of the native range, with the majority of samples from the Czech Republic (30 samples) and Austria (16 samples) followed by Italy ( 5 samples), France and Scotland ( 2 samples, respectively) and single samples from five more countries (Belgium, Croatia, Slovakia, Sweden, and Ukraine), which was realized by using both herbarium and fresh leaf material (see apps. A, B [app. B is in the online edition of the International Journal of Plant Sciences]). Since we aimed to cover a wide geographical range, leaf material was collected from a large number of regions (32) and populations (131), while the number of individuals per population was relatively low (sample sizes between 1 and 15 individuals per population; for similar strategies, see Clausing et al. 2000; Lambracht et al. 2007; Prinz et al. 2009). In the invasive range we mainly sampled populations in Argentina (90 samples), but we also included a few populations from Chile (6 samples), South Africa (1 sample), Australia (1 sample), and New Zealand (16 samples; see app. B). Herbarium material was collected from herbaria in Germany and Austria dating from 1927 to 2002 (see apps. A, B). Fresh leaf material was sampled randomly from areas within the invasive ranges no larger than $2500 \mathrm{~m}^{2}$, and the minimum distance between populations was $1 \mathrm{~km}$. Because of the small population sizes in the native range, the number of sampled individuals per population was often lower than 10 and usually covered the whole population area (area sizes between 0.009 and $0.09 \mathrm{~km}^{2}$; for detailed information, see Zimmermann et al. 2010). Altogether, 417 samples from 29 invasive and 102 native populations were studied (see fig. 1; app. B). To test whether herbarium material was suited for microsatellite analyses, we tested both herbarium (1-2 years old) and fresh material from 10 individuals, which yielded identical results.

\section{DNA Extraction}

DNA extraction from silica gel-dried leaf material was performed with the DNeasy Plant Mini Kit (QIAGEN, Hilden) following the manufacturer's instructions. To increase 


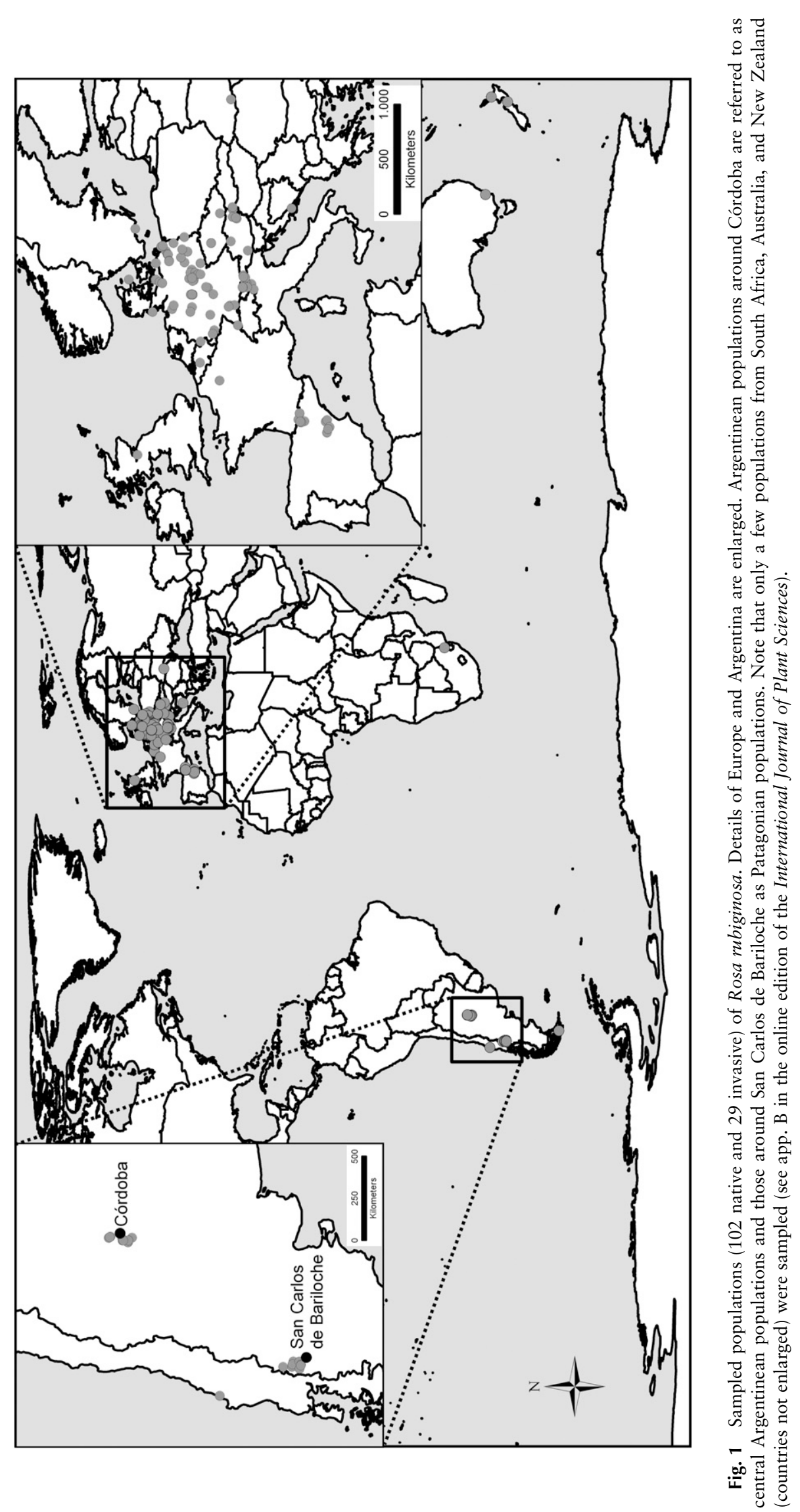



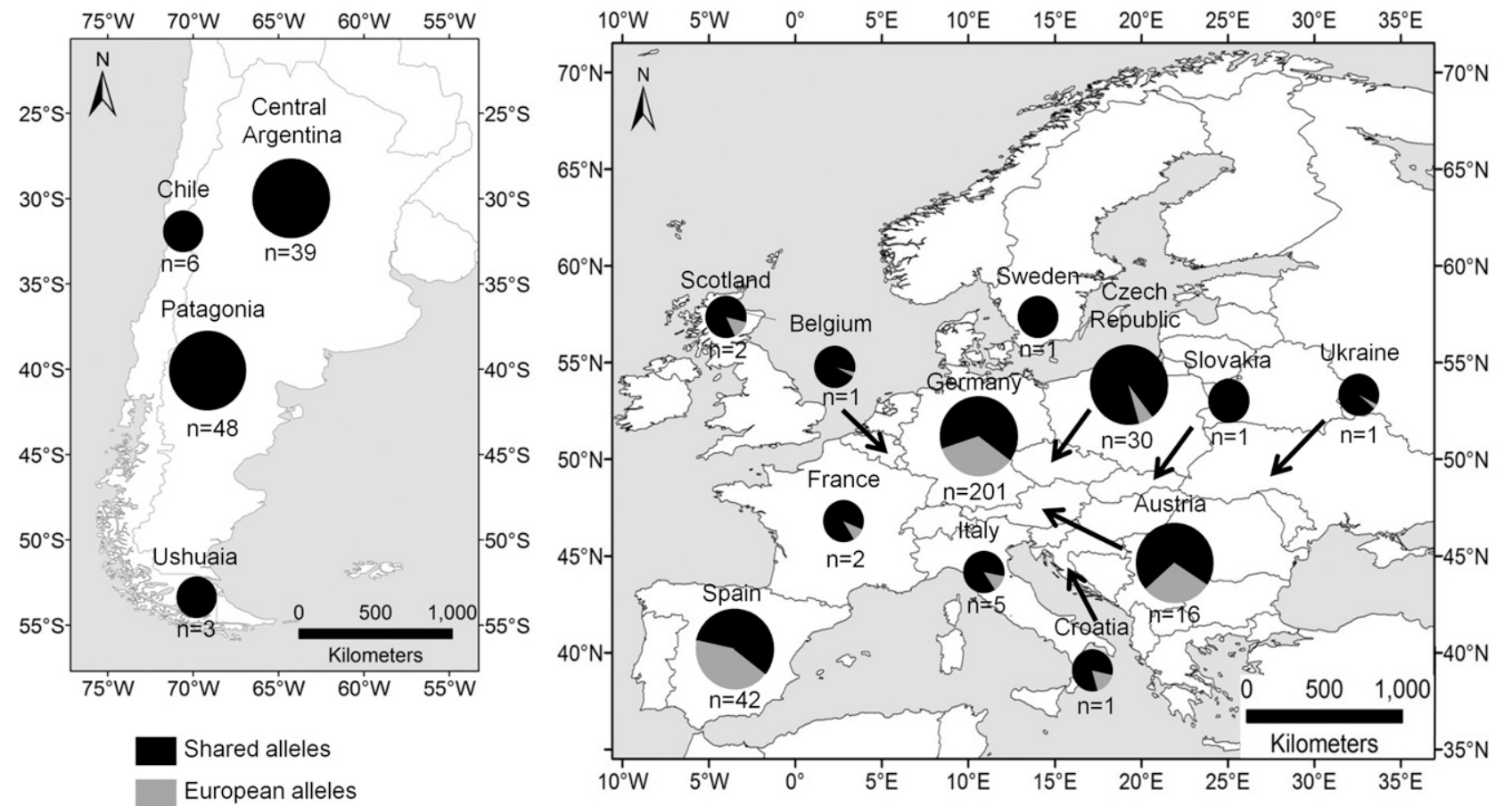

Fig. 2 Allele frequencies of Rosa rubiginosa in Europe and South America (black = alleles found in both Europe and South America, gray = alleles found exclusively in Europe). Individuals sampled within a country are pooled $(n=$ sample size). Countries with sample sizes less than 10 are characterized by having smaller diagrams. The other invasive ranges are excluded because of their small sample sizes. Spain is characterized as having the highest proportion of exclusively European alleles, followed by Germany and Austria. No exclusive alleles were detected in South America.

the final DNA concentration, we used a longer elution time (10 $\mathrm{min})$ for the herbarium samples in accordance with Drábkova et al. (2002).

\section{Microsatellite Analysis}

For the analyses of sequence-tagged microsatellite sites of $R$. rubiginosa, we used eight primer pairs (RhD201, RhD206, RhD221, RhB303, RhEO506, RhP519, RhE2b and RhAB26) isolated by Esselink et al. (2003). PCR assays were set up in final volumes of $25 \mu \mathrm{L}$, containing $10 \mathrm{ng}$ of genomic DNA, $1 \mu \mathrm{L}$ of each primer ( $5 \mathrm{pmol} / \mu \mathrm{L}$; Metabion, Martinsried), $2.5 \mu \mathrm{L}$ dNTPs (2.5 mM; Q-Biogene, Heidelberg), $1 \mathrm{U}$ Taq DNA polymerase (Fermentas, St. Leon-Rot), $2.5 \mu \mathrm{L}$ incubation mix T. Pol with $1.5 \mathrm{mM} \mathrm{MgCl}_{2}$ (Q-Biogene) and $16.8 \mu \mathrm{L}$ $\mathrm{H}_{2} \mathrm{O}_{\text {bidest }}$. One primer of each pair was labeled at the $5^{\prime}$ end with 6-FAM or HEX fluorescent dyes. PCR was performed in a Mastercycler gradient or Mastercycler epgradient (Eppendorf, Hamburg) under the following temperature regime: initial denaturation at $94^{\circ} \mathrm{C}$ for $3 \mathrm{~min} ; 28$ cycles $(35$ cycles for primer $\mathrm{RhD} 201$ and $\mathrm{RhE} 2 \mathrm{~b}$ ) with $30 \mathrm{~s}$ denaturation at $94^{\circ} \mathrm{C}, 30 \mathrm{~s}$ annealing at $50^{\circ} \mathrm{C}$, and $60 \mathrm{~s}$ elongation at $72^{\circ} \mathrm{C}$, and a final elongation step for $3 \mathrm{~min}$ at $72^{\circ} \mathrm{C}$. PCR products (fresh leaf material 1:5 and herbarium leaf material 1:1 diluted) were used for separation on a MegaBace 1000 system (Amersham Bioscience, Uppsala) with MegaBace-ET Rox 400 (Amersham Bioscience) as a size standard. The genotyping was performed with the MegaBace Fragment Profiler software 1.2 (Amersham Bioscience).

\section{Data Analysis}

The eight primer pairs used in the PCR yielded 69 polymorphic alleles. Only four or fewer alleles per locus were detected in any individual at any of the scored loci, which is in accordance with previous results of Nybom et al. (2004) on several dog roses, including $R$. rubiginosa. The assessment of the exact allelic configurations using microsatellite DNA counting-peak ratios in accordance with Esselink et al. (2004) was not successful as a result of significant deviations between observed and expected microsatellite DNA countingpeak ratios. Possible reasons for these deviations include base substitution in the primer binding sites or reaction times exceeding the exponential phase during PCR (Esselink et al. 2003, 2004). Therefore, statistical analysis had to be based on the allelic phenotypes, since the number of allele copies remained unknown.

We calculated the proportions of shared alleles (i.e., alleles occurring in both the native range and the invasive range South America) and exclusively European alleles (i.e., alleles restricted to the native range). This method was previously described by Durka et al. (2005) and assumes that a high proportion of shared alleles indicates the possible source region, whereas unlikely source regions are characterized by a high proportion of exclusively European alleles. Moreover, the proportion of allelic phenotypes was also used as a measure of genetic diversity. In order to reveal genetic similarity between samples, a principal coordinate analysis (PCoA) using square root-transformed Jaccard dissimilarities (equivalent to Jaccard distance, which is obtained by subtracting the 


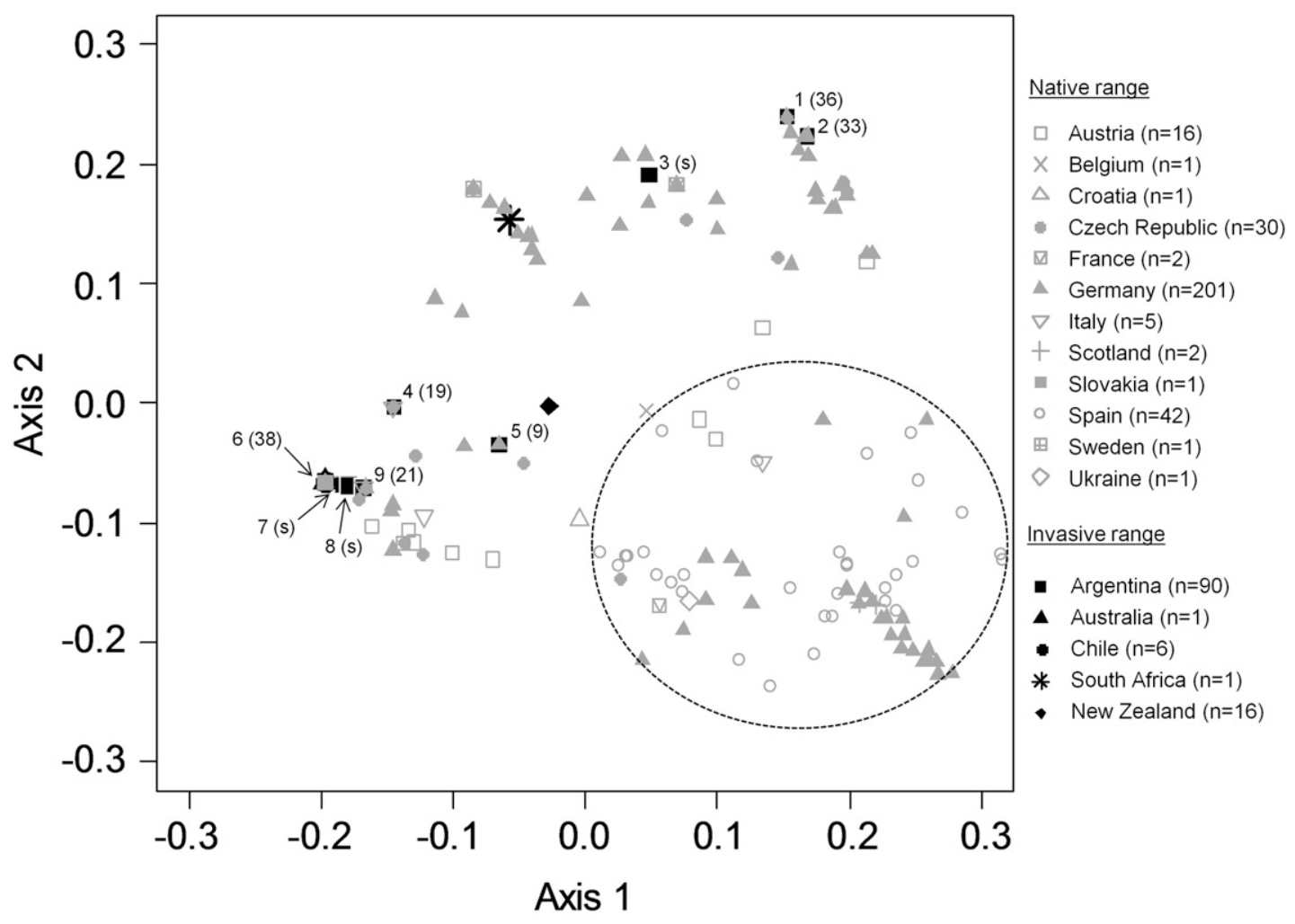

Fig. 3 Principal coordinate analysis (PCoA) of microsatellite data for Rosa rubiginosa (417 samples; PCoA based on square root-transformed Jaccard dissimilarity; explained variance axis $1=22.1 \%$, axis $2=19.4 \%$ ). Each point represents an individual and is coded with a unique symbol for the corresponding country (black $=$ countries in the invasive range, gray $=$ countries in the native range). Note that Argentinean samples are accumulated in only nine visible points (visualized by numbers 1-9; numbers in parentheses correspond to the group ID of groups with identical allelic phenotypes in table 2; $s=$ single allelic phenotype) and show a high similarity or even identicalness with samples from Austria, the Czech Republic, Germany, Italy, and Slovakia. Note that three of the Argentinean groups (groups 1-3; represented by samples from two central Argentinean populations) are grouped separately from the remaining South American samples. Samples from Spain (circled with dashed line) are clearly separated from invasive samples.

Jaccard similarity from 1) was performed with the package vegan (Oksanen et al. 2008) in $\mathrm{R}$ (ver. 2.8.1; R Development Core Team 2008). We used the load on the first three axes of every yielded point in the PCoA and the "find clones" option of GenAlEx 6.1 (Peakall and Smouse 2006) to identify the groups of individuals with identical allelic phenotypes and the sizes of these groups.

Furthermore, we analyzed genetic similarities between populations with pairwise $F_{\mathrm{ST}}^{\prime}$ values, and as a measure of genetic diversity within ranges, the mean Jaccard dissimilarities within the native as well as the invasive range were calculated. For these analyses, only data from populations with three or more sampled individuals (native range, 239 samples; invasive range, 101 samples; see app. B) were selected. Pairwise $F_{\mathrm{ST}}^{\prime}$ values were calculated with the software FDASH. This program was developed by Obbard et al. (2006) for codominant marker analysis of polyploid species with unknown allelic configurations. On the basis of pairwise $F_{\mathrm{ST}}^{\prime}$ values and geographic distances, we performed a Mantel test (Mantel 1967) with the package vegan in $\mathrm{R}$ to test for isolation by distance patterns among Argentinean populations as well as among European populations. Mean Jaccard dissimilarity was calculated (999 permutations; package vegan in R) per country and for both the invasive and the native ranges. Sample number in the native range was more than twice as high as for the invasive range, so the native range mean Jaccard dissimilarity was bootstrapped in order to account for unbalanced sampling.

\section{Results}

The geographical allele distribution (fig. 2) shows high proportions of European alleles in samples from Germany, Spain, and Austria (29.6\%-43.1\%). In contrast, the Czech Republic is characterized by only $5.9 \%$ of European-specific alleles. No exclusive alleles were detected in the invasive range.

The 96 South American samples were clustered in nine groups of individuals with identical allelic phenotypes in the PCoA (fig. 3). Two central Argentinean populations were grouped separately, while the seven remaining groups clustered closely and contained samples from both Argentinean regions as well as Chile. The PCoA revealed a clear distinction between the Spanish and Argentinean Rosa rubiginosa samples. In contrast, several Argentinean allelic phenotypes were very similar or even identical to allelic phenotypes from Germany, the Czech Republic, Austria, Italy, and Slovakia. 


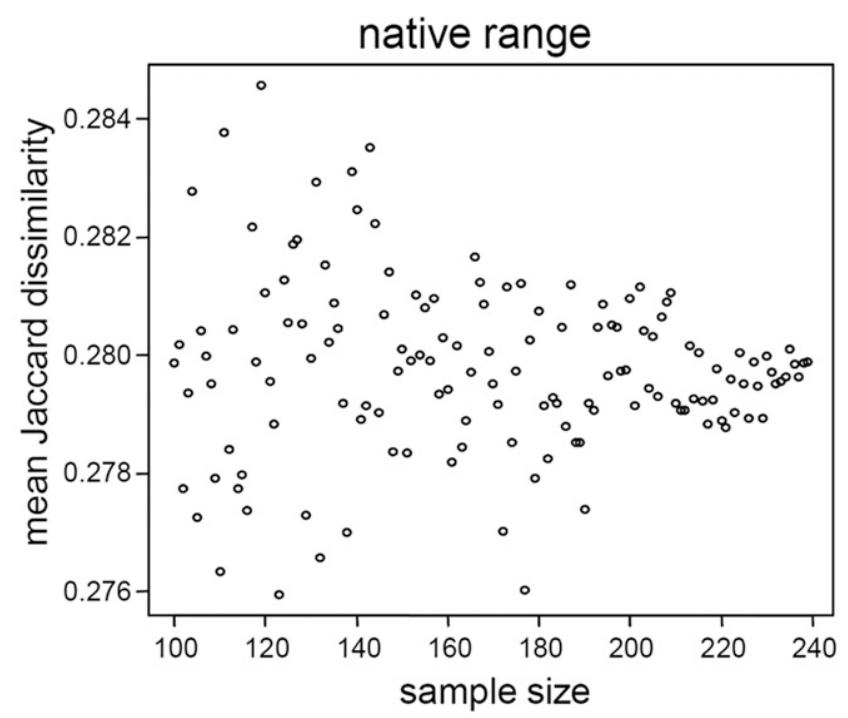

Fig. 4 Bootstrapped mean Jaccard dissimilarity for sample sizes between 100 and 239 in the native range to account for unbalanced sampling between native ( 239 samples) and invasive (101 samples) range. Jaccard dissimilarity is equivalent to Jaccard distance, which is obtained by subtracting the Jaccard similarity from 1 . Mean Jaccard dissimilarity was calculated for the reduced data set, which contains populations with only three or more samples (see app. B in the online edition of the International Journal of Plant Sciences). Bootstrapped values show a very low variation at only less than 0.01 , which excludes a significant influence of sample size on the mean Jaccard dissimilarity.

The Chilean, Australian, and several allelic phenotypes from New Zealand were identical to most Argentinean allelic phenotypes. These results are confirmed by the ranges of Jaccard dissimilarities between European countries and countries from the invasive range (table 1). We detected no exact match between European allelic phenotypes and the single sample from South Africa (table 1).

Levels of pairwise $F_{\mathrm{ST}}^{\prime}$ values between the South American populations of $R$. rubiginosa were very low (0.00-0.04; data not shown). The only exceptions were two central Argentinean populations, which also grouped separately in the PCoA; they shared values between 0.19 and 0.49 with other South American populations. Pairwise $F_{\mathrm{ST}}^{\prime}$ values between these two central Argentinean populations and the New Zealand population were 0.26 and 0.30 , while the values between the New Zealand population and the remaining South American populations were only between 0.00 and 0.10. Among European populations, we found pairwise $F_{\mathrm{ST}}^{\prime}$ values between 0.00 and 0.93. In accordance with the PCoA, the Mantel test revealed no isolation by distance relationship among the European populations (Mantel statistic $r=0.135, P=0.058$ ) or the South American populations $(r=0.014, P=0.259)$.

Calculation of the mean Jaccard dissimilarity per range revealed that diversity in the native range was 4.7 times higher (0.28) than that in the invasive range (0.06). Bootstrapped native range estimates show a very low variation of less than 0.01 (fig. 4). The low genetic variability in the invaded South American and New Zealand ranges was also reflected by the large number of individuals clustered in only few groups of samples with identical allelic phenotypes (table 2; fig. 3). The European allelic phenotypes showed a more diverse pattern. The invasive range also had a smaller number of alleles as well as lower mean Jaccard dissimilarities and a smaller number of allelic phenotypes per locus at the country level than in the native range, except for Italian populations (table 3).

\section{Discussion}

\section{Identification of the Source Region}

Several authors assume that Rosa rubiginosa was introduced to South America by Spanish emigrants (Joublan et al. 1996; Leuenberger 2005; Lüttig 2006); however, this assumption is apparently based on largely unreliable evidence. In contrast, our PCoA and the ranges of Jaccard dissimilarities clearly distinguish between invasive Argentinean populations and native Spanish populations (table 1; fig. 3), suggesting that the origin of the species in Argentina is not Spanish. The results indicate exact or close similarity between Argentinean samples and those from Germany, the Czech Republic, Austria, Italy, and Slovakia. In accordance, populations in Spain had the

Table 1

Ranges of Jaccard Dissimilarities between European Countries and Countries in the Invasion Range

\begin{tabular}{lcllcc}
\hline Country & Argentina & Australia & Chile & New Zealand & South Africa \\
\hline Austria & $.00-.41$ & $.00-.39$ & $.00-.39$ & $.00-.39$ & $.04-.34$ \\
Belgium & $.11-.29$ & .17 & .17 & $.17-.30$ & .23 \\
Croatia & $.27-.44$ & .30 & .30 & $.30-.31$ & .35 \\
Czech Republic & $.00-.35$ & $.00-.32$ & $.00-.32$ & $.00-.39$ & $.11-.31$ \\
France & $.14-.39$ & .23 & .23 & $.23-.35$ & $.17-.34$ \\
Germany & $.00-.44$ & $.00-.36$ & $.00-.36$ & $.00-.42$ & $.04-.39$ \\
Italy & $.00-.39$ & $.04-.34$ & $.04-.34$ & $.04-.35$ & $.11-.29$ \\
Scotland & $.23-.31$ & $.26-.28$ & $.26-.28$ & $.26-.34$ & $.31-.33$ \\
Slovakia & $.00-.26$ & .00 & .00 & $.00-.21$ & .14 \\
Spain & $.07-.61$ & $.11-.59$ & $.11-.59$ & $.11-.59$ & $.04-.61$ \\
Sweden & $.07-.17$ & .11 & .11 & $.11-.18$ & .04 \\
Ukraine & $.14-.36$ & .20 & .20 & $.20-.32$ & .31 \\
\hline
\end{tabular}

Note. Jaccard dissimilarity is equivalent to Jaccard distance, which is obtained by subtracting the Jaccard similarity from 1 . Values of 0 indicate the occurrence of identical allelic phenotypes between two countries. 
Table 2

Groups of Identical Allelic Phenotypes and Geographic Origin of Samples in Each Group

\begin{tabular}{|c|c|c|c|}
\hline Group ID & Group size & Native range & Invasive range \\
\hline 1 & 2 & ES (2) & \\
\hline 2 & 2 & ES (2) & \\
\hline 3 & 2 & DE $(2)$ & \\
\hline 4 & 2 & $\mathrm{DE}(2)$ & \\
\hline 5 & 2 & DE (1), GB (1) & \\
\hline 6 & 2 & ES (2) & \\
\hline 7 & 2 & ES (2) & \\
\hline 8 & 2 & DE (2) & \\
\hline 9 & 2 & $\mathrm{DE}(1)$ & $\operatorname{AR}(1)$ \\
\hline 10 & 2 & DE (2) & \\
\hline 11 & 2 & DE (2) & \\
\hline 12 & 2 & DE (2) & \\
\hline 13 & 2 & DE (2) & \\
\hline 14 & 2 & ES (2) & \\
\hline 15 & 2 & ES (2) & \\
\hline 16 & 3 & DE (3) & \\
\hline 17 & 3 & ES (3) & \\
\hline 18 & 3 & $\mathrm{DE}(3)$ & \\
\hline 19 & 3 & CZ (1), IT (1) & AR (1) \\
\hline 20 & 3 & $\mathrm{CZ}(2), \mathrm{DE}(1)$ & \\
\hline 21 & 3 & IT (2) & $\operatorname{AR}(1)$ \\
\hline 22 & 3 & DE (2), FR (1) & \\
\hline 23 & 3 & DE (3) & \\
\hline 24 & 4 & AT (2), CZ (2) & \\
\hline 25 & 4 & ES (4) & \\
\hline 26 & 5 & $\mathrm{CZ}(5)$ & \\
\hline 27 & 6 & DE (6) & \\
\hline 28 & 7 & $\operatorname{DE}(7)$ & \\
\hline 29 & 7 & $\operatorname{DE}(7)$ & \\
\hline 30 & 7 & DE (7) & \\
\hline 31 & 8 & CZ (8) & \\
\hline 32 & 8 & NZ (8) & \\
\hline 33 & 9 & $\mathrm{DE}(6)$ & AR (3) \\
\hline 34 & 11 & DE (11) & \\
\hline 35 & 13 & DE (13) & \\
\hline 36 & 26 & $\mathrm{CZ}(6), \mathrm{DE}(17)$ & AR (3) \\
\hline 37 & 63 & $\operatorname{AT}(1), \operatorname{DE}(60), \operatorname{ES}(1), \operatorname{SE}(1)$ & \\
\hline 38 & 104 & $\operatorname{AT}(4), \operatorname{CZ}(1), \operatorname{DE}(5)$, SK (1) & $\operatorname{AR}(78), \operatorname{AU}(1), \mathrm{CL}(6), \mathrm{NZ}(8)$ \\
\hline
\end{tabular}

Note. Group size indicates the number of individuals that share the same allelic phenotype. Origin of samples is separated and arranged alphabetically by native range $(\mathrm{AT}=$ Austria, $\mathrm{BE}=$ Belgium, $\mathrm{CZ}=$ Czech Republic, DE = Germany, ES = Spain, FR = France, GB = Great Britain/Scotland, HR = Croatia, $\mathrm{IT}=$ Italy, $\mathrm{SE}=$ Sweden, $\mathrm{SK}=$ Slovakia, $\mathrm{UA}=$ Ukraine $)$ as well as invasive range $(\mathrm{AR}=$ Argentina, $\mathrm{AU}=$ Australia, $\mathrm{CL}=$ Chile, $\mathrm{NZ}=$ New Zealand). Numbers in parentheses indicate samples represented from the corresponding country.

highest proportion of exclusively European alleles, whereas populations from the Czech Republic, Italy, Slovakia, Belgium, Croatia, Scotland, Sweden, Ukraine, and France had relatively small proportions of European alleles. However, the latter six countries were excluded as possible origin regions by the PCoA (fig. 3), while sample sizes of Italian and Slovakian populations were too small to draw any significant conclusions. German and Austrian populations show comparatively high proportions of exclusively European alleles, but they cannot be excluded as possible source regions because of the similarity between some of their samples and South American samples in the PCoA and according to the Jaccard dissimilarity ranges. The allele distribution result for the Czech Republic is in agreement with the PCoA. Furthermore, it is im- portant to mention that the proportion of exclusively European alleles appears to be influenced by the sample size (the smaller the sample size, the higher the proportion of exclusively European alleles), except for the Czech Republic. Therefore, we emphasize the importance of comparing the results of the allele proportions with other statistical analyses that are based on a more exact relation of allelic phenotypes.

Combining all results, we are able to exclude a Spanish origin of the South American populations, and we assume that Central Europe-in particular, Germany, the Czech Republic, Austria, Slovakia, and Italy-constitutes the most probable source region for the South American populations. Narrowing down the geographical range would require more extensive sampling, especially from Austria, Slovakia, and Italy. 
Table 3

Number of Alleles, Average Allelic Phenotypes per Locus, and Mean Jaccard Dissimilarity (999 Permutations) per Country for the Reduced FDASH Data Set

\begin{tabular}{lrccc}
\hline Country & $n$ & No. alleles & $\begin{array}{c}\text { Average allelic } \\
\text { phenotypes per locus }\end{array}$ & $\begin{array}{c}\text { Mean Jaccard } \\
\text { dissimilarity }\end{array}$ \\
\hline Native range: & & & & \\
$\quad$ Czech Republic & 30 & 34 & 2.50 & .19 \\
$\quad$ Germany & 167 & 47 & 5.25 & .22 \\
$\quad$ Italy & 3 & 29 & 1.12 & .03 \\
$\quad$ Spain & 39 & 58 & 8.25 & .38 \\
Invasive range: & & & & .04 \\
$\quad$ Argentina & 81 & 33 & 2.00 & .00 \\
$\quad$ Chile & 5 & 27 & 1.00 & .10 \\
$\quad$ New Zealand & 15 & 29 & 1.37 & \\
\hline
\end{tabular}

Note. $n=$ sample size of each country. FDASH data set includes 340 samples (see app. B in the online edition of the International Journal of Plant Sciences).

Our study confirms the general fact that the exact native source region of an invasive species is difficult to determine, even if advanced molecular tools are applied. Durka et al. (2005), looking for the progenitors of North American invasive Alliaria petiolata (M. Bieb.) Cavara and Grande, also identified a relative wide-ranging area (British Isles, Northern Europe and Central Europe) as a possible source region. Milne and Abbott (2004) showed that invasive Ligustrum robustum populations in the Mascarene Islands originated in Sri Lanka, but it was not possible to detect the exact origin location within Sri Lanka. Even the tracing of source regions at much smaller spatial scales can be complicated. Neither Prinz et al. (2009) nor Esfeld et al. (2008) were able to identify the exact colonization source of newly established populations from former mining areas. Studies using a combination of uniand biparentally inherited DNA sequences seem to be more successful. For instance, Milne and Abbott (2000) identified the Iberian Peninsula as the source region of the invasive Rhododendron ponticum L. populations on the British Isles via chloroplast and nuclear ribosomal DNA restriction fragment length polymorphisms. Combining mitochondrial DNA and microsatellite markers, Rugman-Jones et al. (2007) identified Coatepec Harinas in Mexico as the most likely source region of the invasive Californian populations of the avocado thrips (Scirtothrips perseae Nakahara). However, in the case of $R$. rubiginosa, we expect that an analysis with maternally inherited DNA would not show a more informative result than the matroclinal inherited microsatellites. Olsson et al. (2000) assume a conservative force in the maternal-biased inheritance of nonorganelle DNA markers in the section Caninae that leads to a comparability of matroclinal and uniparental inheritance. Our assumption is also confirmed by the results of Wissemann and Ritz (2005), who show that established chloroplast DNA markers are not suitable to find differentiations within and between the subsections Rubiginae (including R. rubiginosa) and Vestitae.

On the basis of historical evidence, it is assumed that $R$. rubiginosa was introduced to Patagonia $\sim 1900$ (Damascos 1992). The hypothesis that Spanish emigrants introduced the rose is probably based on the fact that most ancestors of the Argentineans were Spanish. However, the Argentinean government promoted the immigration of other Europeans to
Argentina following the end of Spanish colonial rule in 1816 (Oelsner 2007). Thus, especially Italian, French, German, Austrian, British, Belgian, and Swiss emigrants reached Argentina during a mass immigration in the second half of the nineteenth century. For example, 21,831 Germans, 26,335 Austrians, and 838,267 Italians arrived in Argentina in the years between 1877 and 1897 (Oelsner 2007). It is most likely that emigrants from the region of today's Czech Republic were among the Austrians, since this area was, at the time, part of the Austro-Hungarian monarchy, and all citizens of this region travelled with Austrian passports, rendering any estimation of more detailed proportions difficult ( $U$. Prutsch, personal communication).

An introduction to Argentina via Chile cannot be excluded, because central European immigrants began arriving in Chile prior to arriving in Argentina (Liga Chileno-Alemana 1950; Bernecker 1997). This idea of indirect introduction-or the so-called bridgehead effect (Estoup and Guillemaud 2010; Lombaert et al. 2010)-is supported by the identical allelic phenotypes between the Chilean and most of the Argentinean samples. Surprisingly, we also detected identical allelic phenotypes between the Australian, New Zealand, and South American samples and low pairwise $F_{S T}^{\prime}$ values between the New Zealand population and most South American populations. We assume a mixed introduction history in these regions, but additional investigations would be required to arrive at any definitive conclusions.

Identical allelic phenotypes across Argentina suggest a joint origin of Patagonian and central Argentinean populations, which has also been discussed in previous work by Zimmermann et al. (2010). It is assumed that $R$. rubiginosa was first introduced to Patagonia and later transported to central Argentina. Furthermore, we suggest that $R$. rubiginosa was introduced to Argentina at least twice, considering that two of the central Argentinean populations were separated in the PCoA (fig. 3). Both populations are located only $13 \mathrm{~km}$ away from Villa General Belgrano, a village with descendants mainly of German, Swiss, and North Italian origin. It is possible that their ancestors introduced R. rubiginosa independently from the introduction in Patagonia. Usage of R. rubiginosa as living livestock fences due to its dense growth form as well as the traditional usage of rose hips for the production of jam 
and tea are given as possible reasons for the introduction in areas outside of the native range (Damascos 1992; Joublan et al. 1996).

\section{Genetic Diversity and Structure}

The comparison of mean Jaccard dissimilarities, groups with identical allelic phenotypes, number of alleles, average number of allelic phenotypes per locus, and pairwise $F_{\mathrm{ST}}^{\prime}$ values between native and invasive ranges confirms a very low genetic variability for invasive $R$. rubiginosa populations in Argentina and New Zealand, which is in accordance with the previous study by Zimmermann et al. (2010). We assume that this lack of variability in invasive Argentinean R. rubiginosa populations is due to the low number of introduction events and predominantly clonal growth or apomixis (Novak and Mack 2005). For instance, Xu et al. (2003) detected an extremely low genetic diversity in invasive populations of alligator weed (Alternanthera philoxeroides (Mart.) Griseb) in China and suggested that they originated from only a very low number of introduced clones. Furthermore, Prentis et al. (2009) showed that invasive Macfadyena unguis-cati (L.) A. H. Gentry populations in Africa, Australia, Europe, North America, and the Pacific Islands are characterized by very low genetic diversity, and they assume a single or, at best, a few introductions in the invasive range. To estimate the introduction events in New Zealand, more samples would be needed from this range. Nevertheless, R. rubiginosa is one of the examples that introduced species can develop successful invading populations despite reduced genetic diversity (Dlugosch and Parker 2008b).

Both the PCoA and the Mantel test showed that genetic structures in European R. rubiginosa are not linked to geographical patterns. Such a result might indicate an intensive gene flow, but this is unlikely because of the large distances between the European populations and the partly high pair- wise $F_{\mathrm{ST}}^{\prime}$ values. A more likely scenario is that some genotypes had rapidly and homogeneously dispersed during the postglacial recolonization of Europe and were conserved via self-fertilization or apomixis. A microsatellite analysis by Ritz and Wissemann (2011) revealed a high level of genetic identity between open pollinated offspring and mother plants of $R$. rubiginosa. This result is in line with that of Olsson (1999), who also indicated R. rubiginosa as an usually homogenous species. Consequently, self-fertilization might play an important role in native populations and could also explain the successful establishment of $R$. rubiginosa in spite of its reduced genetic variability.

\section{Acknowledgments}

Many thanks to H. Henker and B. Wittig for pointing us to Rosa rubiginosa populations in Germany and to M. Damascos, D. Bran, M. Svriz, P. Marcora, L. Volkmann, and J. Neme for doing so in Argentina. Our thanks go out to E. Vitek for his extensive help in the herbarium of the Natural History Museum in Vienna, L. Martins in the herbarium of the Free University Berlin, and H. Kuhbier in the herbarium of the Überseemuseum in Bremen. We also thank P. Williams for sampling rose populations in New Zealand, K. Mičieta in Slovakia, P. Petrík and V. Wagner in the Czech Republic, and C. Stahr in Germany. We are grateful to N. Fuentes for providing information about the emigration events in Chile. Birgit Müller provided invaluable assistance in the lab, and W. Durka took his time to look over our genetic analysis. We thank D. Esselink of Plant Research International B.V., Wageningen, the Netherlands, for providing us with primers of the microsatellite loci and D. McCluskey for polishing our English. Darren J. Obbard was so kind to provide us with the software FDASH. This study was funded by the DAAD, DFG, and BMZ.

\section{Appendix A}

\section{Source of Specimens from Public Herbaria}

Each entry includes voucher number, the number that corresponds to the serial number in the complete population list (see app. B in the online edition of International Journal of Plant Sciences), locality (administrative classification, region, country), sampling year, and herbarium code from the herbarium where the material was collected $(B=$ Herbarium of the Free University Berlin; W = Herbarium of the Natural History Museum Vienna). Entries are arranged alphabetically by country and region (E = east, $\mathrm{N}=$ north, $\mathrm{NE}=$ northeast, $\mathrm{NW}=$ northwest, $\mathrm{S}=$ south, $\mathrm{SW}=$ southwest, $\mathrm{W}=$ west).

Taxon; voucher number; serial number corresponding to appendix B; collection locale; sampling year; herbarium.

Rosa rubiginosa L.; 1957-9916; 10; Río Negro, Patagonia, Argentina; 1945; W. R. rubiginosa L.; 1986-04693; 31; Spittal an der Drau, Kärnten, Austria; 1985; W. R. rubiginosa L.; 2004-17296; 32; Bruck an der Leitha, Lower Austria, Austria; 1979; W. R. rubiginosa L.; 2005-13042; 33; Vienna, Lower Austria, Austria; 2001; W. R. rubiginosa L.; 2003-04737; 34; Wiener Neustadt, Lower Austria, Austria; 2002; W. R. rubiginosa L.; 2006-10460; 35; Wiener Neustadt, Lower Austria, Austria; 2005; W. R. rubiginosa L.; B100400004; 36; Linz (city), Upper Austria, Austria; 1950; B. R. rubiginosa L.; 1984-04895; 37; Imst, Tyrol, Austria; 1983; W. R. rubiginosa L.; 1992-14972; 38; Imst, Tyrol, Austria; 1991; W. R. rubiginosa L.; 1991-05721; 39; Innsbruck-Land, Tyrol, Austria; 1990; W. R. rubiginosa L.; B100400005; 40; Innsbruck-Land, Tyrol, Austria; 1939 ; B. R. rubiginosa L.; 1989-04417; 41; Innsbruck-Land, Tyrol, Austria; 1988; W. R. rubiginosa L.; 1981-08425; 42; Innsbruck, Tyrol, Austria; 1980; W. R. rubiginosa L.; 1984-04894; 43; Landeck, Tyrol, Austria; 1983; W. R. rubiginosa L.; 1981-08426; 44; Landeck, Tyrol, Austria; 1980; W. R. rubiginosa L.; 1996-02949; 45; Reutte, Tyrol, Austria; 1990; W. R. rubiginosa L.; 199105737; 46; Reutte, Tyrol, Austria; 1990; W. R. rubiginosa L.; B10040006; 25; New South Wales, SW Australia, Australia; 1967; B. R. rubiginosa L.; 1983-04453; 47; Vlaams Brabant, S Flanders, Belgium; 1955; W. R. rubiginosa L.; B100121112; 27; Región del Bío-Bío, Central Chile, Chile; 2002; B. R. rubiginosa L.; 1956-1257; 48; Splitsko-Dalmatinska, S Croatia, Croatia; 
1927; W. R. rubiginosa L.; 1962-13708; 54; Oise, N France, France; 1960; W. R. rubiginosa L.; B100400010; 55; Haut-Rhin, E France, France; 1989; B. R. rubiginosa L.; B100400003; 56; Sachsen-Anhalt, Middle Germany, Germany; 1980; B. R. rubiginosa L.; B100400002; 72; Brandenburg, NE Germany, Germany; 1972; B. R. rubiginosa L.; B100400009; 73; Brandenburg, NE Germany, Germany; 1955; B. R. rubiginosa L.; B100400001; 74; Brandenburg, NE Germany, Germany; 1953; B. R. rubiginosa L.; B100400013; 75; Brandenburg, NE Germany, Germany; 1989; B. R. rubiginosa L.; B10040012; 76; Brandenburg, NE Germany, Germany; 1989; B. R. rubiginosa L.; B100052063; 103; Baden-Württemberg, S Germany, Germany; 1994 ; B. R. rubiginosa L.; 2000-05437; 111; Nordrhein-Westfalen, W Germany, Germany; 1985; W. R. rubiginosa L.; 1981-11830; 115; Sondrio, Tyrol, Italy; 1980; W. R. rubiginosa L.; 1961-16176; 30; Limpopo, NE South Africa, South Africa; 1960;

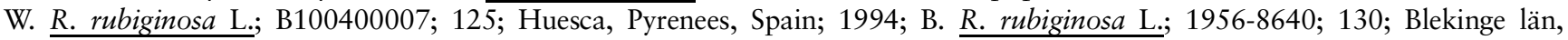
S Sweden, Sweden; 1949; W. R. rubiginosa L.; B100400008; 131; Chernivtsi, W Ukraine, Ukraine; $1992 ; \mathrm{B}$.

\section{Literature Cited}

$\rightarrow$ Ahmad R, P-S Liow, DF Spencer, M Jasieniuk 2008 Molecular evidence for a single genetic clone of invasive Arundo donax in the United States. Aquat Bot 88:113-120.

$\rightarrow$ Barrett SCH, RI Colautti, CG Eckert 2008 Plant reproductive systems and evolution during biological invasion. Mol Ecol 17:373-383.

Barrett SCH, JS Shore 1989 Isozyme variation in colonizing plants. Pages 106-126 in DE Soltis, PS Soltis, eds. Isozymes in plant biology. Dioscorides, Portland, OR.

$\rightarrow$ Bellingham PJ, RP Duncan, WG Lee, RP Buxton 2004 Seedling growth rate and survival do not predict invasiveness in naturalized woody plants in New Zealand. Oikos 106:308-316.

Bernecker WL 1997 Siedlungskolonien und Elitenwanderung. Deutsche in Lateinamerika: Das 19. Jahrhundert. Matices Zeitschrift zu Lateinamerika, Spanien und Portugal 15. http://www.matices.de/ 15/15ssiedl.htm.

$\rightarrow$ Besnard G, P Henry, L Wille, D Cook, E Chapuis 2007 On the origin of the invasive olives (Olea europaea L., Oleaceae). Heredity 99: 608-619.

Blackburn KB, JWH Harrison 1921 The status of the British rose forms as determined by their cytological behaviour. Ann Bot 35: 159-188.

$\rightarrow$ Bossdorf O, H Auge, L Lafuma, WE Rogers, E Siemann, D Prati 2005 Phenotypic and genetic differentiation between native and introduced plant populations. Oecologia 144:1-11.

$\rightarrow$ Clausing G, K Vickers, JW Kadereit 2000 Historical biogeography in a linear system: genetic variation of sea rocket (Cakile maritima) and sea holly (Eryngium maritimum) along European coasts. Mol Ecol 9:1823-1833.

Damascos MA 1992 La rosa mosqueta y la flora andino-patagónica. Cienc Hoy 4:36-39.

Damascos MA, GG Gallopin 1992 Ecología de un arbusto introducido (Rosa rubiginosa $\mathrm{L} .=$ Rosa eglanteria $\mathrm{L}$.): riesgo de invasión y efectos en las comunidades vegetales de la región andino-patagónica de Argentina. Rev Chil Hist Nat 65:395-407.

$\rightarrow$ Dlugosch KM, IM Parker 2008a Founding events in species invasions: genetic variation, adaptive evolution, and the role of multiple introductions. Mol Ecol 17:431-449.

$\rightarrow-2008 b$ Invading populations of an ornamental shrub show rapid life history evolution despite genetic bottlenecks. Ecol Lett 11: 701-709.

$\rightarrow$ Drábkova L, J Kirschner, C Vlcek 2002 Comparison of seven DNA extraction and amplification protocols in historical herbarium specimens of Juncaceae. Plant Mol Biol Rep 20:161-175.

$\rightarrow$ Durka W, O Bossdorf, D Prati, H Auge 2005 Molecular evidence for multiple introductions of garlic mustard (Alliaria petiolata, Brassicaceae) to North America. Mol Ecol 14:1697-1706.

$\rightarrow$ Erfmeier A, H Bruelheide 2005 Invasive and native Rhododendron ponticum populations: is there evidence for genotypic differences in germination and growth? Ecography 28:417-428.

$\rightarrow$ Esfeld K, I Hensen, K Wesche, SS Jakob, S Tischew, FR Blattner 2008 Molecular data indicate multiple independent colonizations of former lignite mining areas in eastern Germany by Epipactis palustris (Orchidaceae). Biodivers Conserv 17:2441-2453.

$\rightarrow$ Esselink GD, H Nybom, B Vosman 2004 Assignment of allelic configuration in polyploids using the MAC-PR (microsatellite DNA allele counting-peak ratios) method. Theor Appl Genet 109:402-408.

Esselink GD, MJM Smulders, B Vosman 2003 Identification of cut rose (Rosa hybrida) and rootstock varieties using robust sequence tagged microsatellite site markers. Theor Appl Genet 106:277-286.

$\rightarrow$ Estoup A, T Guillemaud 2010 Reconstructing routes of invasion using genetic data: why, how and so what? Mol Ecol 19:4113-4130.

$\rightarrow$ Gaskin JF, D-Y Zhang, M-C Bon 2005 Invasion of Lepidium draba (Brassicaceae) in the western United States: distributions and origins of chloroplast DNA haplotypes. Mol Ecol 14:2331-2341.

$\rightarrow$ Goolsby JA, PJ De Barro, JR Makinson, RW Pembertons, DM Hartley, DR Frohlich 2006 Matching the origin of an invasive weed for selection of a herbivore haplotype for a biological control programme. Mol Ecol 15:287-297.

$\rightarrow$ Guo Q 2006 Intercontinental biotic invasions: what can we learn from native populations and habitats? Biol Invasions 8:1451-1459.

$\rightarrow$ Hierro JL, JL Maron, RM Callaway 2005 A biogeographical approach to plant invasions: the importance of studying exotics in their introduced and native range. J Ecol 93:5-15.

Joublan JP, M Berti, H Serri, R Wilckens, F Hevia, I Figueroa 1996 Wild rose germplasm evaluation in Chile. Pages 584-588 in J Janick, ed. Progress in new crops. ASHS, Arlington, VA.

Joublan JP, D Rios 2005 Rose culture and industry in Chile. Acta Hortic 690:65-70.

Lambracht E, E Westberg, JW Kadereit 2007 Phylogeographic evidence for the postglacial colonization of the North and Baltic Sea coasts from inland glacial refugia by Triglochin maritima L. Flora 202:79-88.

$\rightarrow$ Le Roux JJ, AM Wieczorek, J-Y Meyer 2008 Genetic diversity and structure of the invasive tree Miconia calvescens in pacific islands. Divers Distrib 14:935-948.

Leuenberger M 2005 Das schmale Blütenblatt. Weleda Nachrichten 240:3-7.

Liga Chileno-Alemana 1950 Los alemanes en Chile en su primer centenario: resumen historico de la colonización Alemana de las provincias del sur de Chile. Liga Chileno-Alemana, Santiago de Chile.

Litt M, JA Luty 1989 A hypervariable microsatellite revealed by in vitro amplification of a dinucleotide repeat within the cardiac muscle actin gene. Am J Hum Genet 44:397-401.

$\rightarrow$ Lombaert E, T Guillemaud, J-M Cornuet, T Malausa, B Facon, A Estoup 2010 Bridgehead effect in the worldwide invasion of the biocontrol harlequin ladybird. PLoS ONE 5:e9743.

Lüttig A 2006 Rosenrot und Hagebutten. Wild- und Gartenrosen. Kasten, Berlin.

Mantel N 1967 The detection of disease clustering and a generalized regression approach. Cancer Res 27:209-220.

Meusel H, EJ Jäger, E Weinert 1965 Vergleichende Chorologie der zentraleuropäischen Flora. Fischer, Jena. 
$\rightarrow$ Meyerson LA, HA Mooney 2007 Invasive alien species in an era of globalization. Front Ecol Environ 5:199-208.

$\rightarrow$ Milne RI, RJ Abbott 2000 Origin and evolution of invasive naturalized material of Rhododendron ponticum L. in the British Isles. Mol Ecol 9:541-556.

$\rightarrow-2004$ Geographic origin and taxonomic status of the invasive privet, Ligustrum robustum (Oleaceae), in the Mascarene islands, determined by chloroplast DNA and RAPDs. Heredity 92:78-87.

$\rightarrow$ Muirhead JR, DK Gray, DW Kelly, SM Ellis, DD Heath, HJ Macisaac 2008 Identifying the source of species invasions: sampling intensity vs. genetic diversity. Mol Ecol 17:1020-1035.

Nel JL, DM Richardson, M Rouget, TN Mgidi, N Mdzeke, DC Le Maitre, BW van Wilgen, L Schonegevel, L Henderson, S Neser 2004 A proposed classification of invasive alien plant species in South Africa: towards prioritizing species and areas for management action. S Afr J Sci 100:53-64.

$\rightarrow$ Novak SJ, RN Mack 2001 Tracing plant introduction and spread: genetic evidence from Bromus tectorum (Cheatgrass). BioScience 51:114-122.

2005 Genetic bottlenecks in alien plant species: influence of mating systems and introduction dynamics. Pages 201-228 in DF Sax, JJ Stachowicz, SD Gaines, eds. Species invasions: insights into ecology, evolution, and biogeography. Sinauer, Sunderland, MA.

Nybom H, GD Esselink, G Werlemark, B Vosman 2004 Microsatellite DNA marker inheritance indicates preferential pairing between two highly homologous genomes in polyploid and hemisexual dog-roses, Rosa L. Sect. Caninae DC. Heredity 92:139-150.

$\rightarrow$ Obbard DJ, SA Harris, JR Pannell 2006 Simple allelic-phenotype diversity and differentiation statistics for allopolyploids. Heredity 97:296-303.

Oelsner V 2007 Die europäische Einwanderung in Argentinien 18101914. Politikkonzepte, staatliche Förderungen und Auswirkungen auf die argentinische Arbeitswelt. Themenportal Europäische Geschichte. http://www.europa.clio-online.de/2007/Article=254.

Oksanen J, R Kindt, P Legendre, B O'Hara, GL Simpson, P Solymos, MHH Stevens, H Wagner 2008 Vegan: community ecology package. R package version 1.15-1. http://vegan.r-forge.r-project.org/

Olsson $\AA 1999$ Morphometric and molecular variation in the Nordic dogroses (Rosa sect. Caninae, Rosaceae). PhD diss. Lund University.

$\rightarrow$ Olsson Å, H Nybom, HC Prentice 2000 Relationships between Nordic dogroses (Rosa L. sect. Caninae, Rosaceae) assessed by RAPDs and ellipitc Fourier analysis of leaflet shape. Syst Bot 25:511-521.

Parsons WT, EG Cuthbertson 2001 Noxious weeds of Australia. CSIRO, Collingwood.

$\rightarrow$ Peakall R, PE Smouse 2006 GENALEX 6: genetic analysis in Excel. Population genetic software for teaching and research. Mol Ecol Notes 6:288-295.

$\rightarrow$ Prentis PJ, DP Sigg, S Raghu, K Dhileepan, A Pavasovic, AJ Lowe 2009 Understanding invasion history: genetic structure and diversity of two globally invasive plants and implications for their management. Divers Distrib 15:822-830.

$\rightarrow$ Prentis PJ, JRU Wilson, EE Dormontt, DM Richardson, AJ Lowe 2008 Adaptive evolution in invasive species. Trends Plant Sci 13: 288-294.

$\rightarrow$ Prinz K, K Weising, I Hensen 2009 Genetic structure of coastal and inland populations of the annual halophyte Suaeda maritima (L.) Dum. in central Europe, inferred from amplified fragment length polymorphism markers. Plant Biol 11:812-820.
Prinzing A, W Durka, S Klotz, R Brandl 2002 Which species become aliens? Evol Ecol Res 4:385-405.

R Development Core Team. 2008. R: a language and environment for statistical computing. R Foundation for Statistical Computing, Vienna.

$\rightarrow$ Richardson DM, P Pyšek, M Rejmánek, MG Barbour, FD Panetta, CJ West 2000 Naturalization and invasion of alien plants: concepts and definitions. Divers Distrib 6:93-107.

$\rightarrow$ Ritz CM, V Wissemann 2003 Male correlated non-matroclinal character inheritance in reciprocal hybrids of Rosa section Caninae (DC.) Ser. (Rosaceae). Plant Syst Evol 241:213-221.

2011 Microsatellite analyses of artificial and spontaneous dogrose hybrids reveal the hybridogenic origin of Rosa micrantha by the contribution of unreduced gametes. J Hered 102, doi: 10.1093/jhered/esq124.

$\rightarrow$ Rugman-Jones PF, MS Hoddle, R Stouthamer 2007 Population genetics of Scirtothrips perseae: tracing the origin of a recently introduced exotic pest of Californian avocado orchards, using mitochondrial and microsatellite DNA markers. Entomol Exp Appl 124:101-115.

$\rightarrow$ Sakai AK, FW Allendorf, JS Holt, DM Lodge, J Molofsky, KA With, S Baughman, et al 2001 The population biology of invasive species. Annu Rev Ecol Syst 32:305-332.

$\rightarrow$ Schlaepfer DR, M Glättli, M Fischer, M Van Kleunen 2010 A multispecies experiment in their native range indicates pre-adaptation of invasive alien plant species. New Phytol 185:1087-1099.

$\rightarrow$ Soltis PS, DE Soltis 2000 The role of genetic and genomic attributes in the success of polyploids. Proc Natl Acad Sci USA 97:7051-7057.

Täckholm G 1920 On the cytology of the genus Rosa: a preliminary note. Sven Bot Tidskr 14:300-311.

1922 Zytologische Studien über die Gattung Rosa. Acta Horti Bergiani 7:97-381.

$\rightarrow$ Tautz D 1989 Hypervariability of simple sequences as a general source for polymorphic DNA markers. Nucleic Acids Res 17:64636471.

Weber E 2003 Invasive plant species of the world: a reference guide to environmental weeds. CABI, Cambridge.

Wissemann V, F Gallenmuller, C Ritz, T Steinbrecher, T Speck 2006 Inheritance of growth form and mechanical characters in reciprocal polyploid hybrids of Rosa section Caninae: implications for the ecological niche differentiation and radiation process of hybrid offspring. Trees Struct Funct 20:340-347.

Wissemann V, FH Hellwig 1997 Reproduction and hybridisation in the genus Rosa section Caninae (Ser.). Rehd. Bot Acta 110:251256.

$\rightarrow$ Wissemann V, CM Ritz 2005 The genus Rosa (Rosoideae, Rosaceae) revisited: molecular analysis of nrITS- 1 and $a t p \mathrm{~B}-r b c \mathrm{~L}$ intergenic spacer (IGS) versus conventional taxonomy. Bot J Linn Soc 144: 275-290.

$\rightarrow-2007$ Evolutionary patterns and processes in the genus Rosa (Rosaceae) and their implications for host-parasite co-evolution. Plant Syst Evol 266:79-89.

$\rightarrow$ Xu CY, WJ Zhang, CZ Fu, BR Lu 2003 Genetic diversity of alligator weed in China by RAPD analysis. Biodivers Conserv 12:637-645.

Zimmermann H, CM Ritz, H Hirsch, D Renison, K Wesche, I Hensen 2010 Highly reduced genetic diversity of Rosa rubiginosa L. populations in the invasive range. Int J Plant Sci 171:435446. 